IZA DP No. 5815

Part-Time Work, Fixed-Term Contracts, and the Returns to Experience

Daniel Fernández-Kranz

Marie Paul (née Waller)

Núria Rodríguez-Planas

June 2011 


\title{
Part-Time Work, Fixed-Term Contracts, and the Returns to Experience
}

\author{
Daniel Fernández-Kranz \\ IE Business School \\ Marie Paul (née Waller) \\ Albert-Ludwigs-University Freiburg \\ Núria Rodríguez-Planas \\ Universitat Autònoma de Barcelona \\ MOVE, Barcelona GSE and IZA
}

\author{
Discussion Paper No. 5815 \\ June 2011
}

\author{
IZA \\ P.O. Box 7240 \\ 53072 Bonn \\ Germany \\ Phone: +49-228-3894-0 \\ Fax: +49-228-3894-180 \\ E-mail: iza@iza.org
}

\begin{abstract}
Any opinions expressed here are those of the author(s) and not those of IZA. Research published in this series may include views on policy, but the institute itself takes no institutional policy positions.

The Institute for the Study of Labor (IZA) in Bonn is a local and virtual international research center and a place of communication between science, politics and business. IZA is an independent nonprofit organization supported by Deutsche Post Foundation. The center is associated with the University of Bonn and offers a stimulating research environment through its international network, workshops and conferences, data service, project support, research visits and doctoral program. IZA engages in (i) original and internationally competitive research in all fields of labor economics, (ii) development of policy concepts, and (iii) dissemination of research results and concepts to the interested public.
\end{abstract}

IZA Discussion Papers often represent preliminary work and are circulated to encourage discussion. Citation of such a paper should account for its provisional character. A revised version may be available directly from the author. 


\section{ABSTRACT \\ Part-Time Work, Fixed-Term Contracts, and the Returns to Experience*}

Using data from Spanish Social Security records, we investigate the returns to experience in different flexible work arrangements, including part-time and full-time work, and permanent and fixed-term contracts. We use a trivariate random effects model which consists of a threeequation system that is estimated simultaneously by Markov Chain Monte Carlo techniques. Our results indicate that there is a large pay gap for working part-time which persists many years after having resumed full-time work. We also find that working part-time involves lower returns to experience than standard full-time employment and thus a substantial negative wage differential for those employed part-time accumulates over time. Finally, we find that heterogeneity exist by contract type and motherhood status.

JEL Classification: J16, J24, J31, J41, C11, C33

Keywords: fixed-term and permanent contracts, part-time employment, returns to experience of differential work histories, random effects models, MCMC, motherhood

Corresponding author:

Núria Rodríguez-Planas

Unitat de Fonaments de l'Anàlisi Econòmica

Edifici B

Universitat Autònoma de Barcelona

08193 Bellaterra

Spain

E-mail: Nuria.Rodriguez@uab.es

\footnotetext{
* We are very grateful to participants of the workshop "Increasing Labor Market Flexibility: Boom or Bane?" at the Institute for Employment Research, Nuremberg. Núria Rodríguez-Planas acknowledges financial support from the Spanish ministry of Education and Science (grant SEJ2006-712), the Generalitat de Catalunya (grant SGR2005-712), and Barcelona GSE. Daniel Fernández-Kranz acknowledges financial support from the Spanish Ministry of Education and Science (grant ECO200907237). Marie Paul acknowledges financial support by the Scientific Community of Freiburg. Finally, Núria Rodríguez-Planas is affiliated to Barcelona Graduate School of Economics and MOVE in Barcelona, IZA in Bonn, and FEDEA in Madrid, and greatly appreciates their support.
} 


\section{Introduction}

In the last three decades, marginal work arrangements involving part-time (PT) work or fixed-term contracts have surged in many Continental European countries as a means to increase flexibility in the labour market. At the same time, regular jobs in these countries have maintained their strong employment protection. As a consequence, many researchers and policy makers are concerned of a deepening segmentation of the labour market, with insiders (those with permanent full-time contracts) enjoying better work conditions than outsiders (those under flexible work). At the macroeconomic level, this is particularly worrisome if the coexistence of two types of contracts gives rise to a soaring unemployment rate as the one observed in the recent economic crisis in Spain—as Bentolila et. al., 2010, demonstrate in a recent paper using a calibrated search and matching model. At the microeconomic level, the concern is that those who are employed under a flexible work arrangement may experience worse work conditions than those with permanent full-time contracts. The issue is particularly relevant for female workers, since women tend to be overrepresented in flexible work arrangements. ${ }^{1}$ Supporters of such type of work arrangements argue, however, that they are helpful in reconciling market and family work, or that they work as stepping-stones from non-employment into standard employment arrangements.

This debate has led to a large literature estimating the effect of flexible work, especially PT work, on women's labour outcomes. Within this literature, many researchers have analyzed the hourly wage differences between PT workers and their full-time (FT) counterparts. A frequent concern when estimating this difference is that workers in flexible work arrangements may have different unobserved productivity, tastes and preferences for work than those with more standard types of jobs. One way to address the unobserved heterogeneity problem is to use panel data and to estimate a fixed-effects- 'within' estimator,

\footnotetext{
${ }^{1}$ See Blank, 1998; Aaronson and French, 2004; Manning and Petrongolo, 2008; and Booth and Wood, 2008, among others, for papers analyzing the PT/FT hourly wage differential. And Jimeno and Toharia, 1993; Blanchard and Landier, 2002; Booth et al., 2002; Dolado, et al., 2002, and De la Rica, 2004 for papers analyzing the hourly wage differential between fixed-term and permanent contract workers.
} 
in which case, the effect of PT on wages is identified through those workers who switch status (see Booth and Wood, 2008; Connolly and Gregory, 2009; and Fernández-Kranz and Rodríguez-Planas (forthcoming)). ${ }^{2}$ However, three additional concerns (not addressed in the literature until now) emerge. First, PT workers may have, on average, very different work histories than FT workers. They are likely to have experienced prior PT spells and interruptions and they may have more or less of their experience obtained under fixed-term contracts. Second, the contract type decisions may depend on past and current PT decisions. If the wage returns to experience differ by the work arrangement in which it is obtained, and by the timing and sequencing of the obtained experience, differences in histories between PT and FT workers should be taken into account to analyze the PT/FT wage differential. Finally, it must not be neglected that the work history is a sum of many decisions in the past, for which selection based on observables and unobserved heterogeneity may again have played an important role. The central point of this article is to account for experience and its dimensions in such a comprehensive way.

Our paper is the first to estimate the wage effect of PT work for female workers after accounting for individual heterogeneity, the selection into employment, PT work and contract decisions based on time-constant unobserved heterogeneity, and dealing comprehensively with differences in work experience while accounting for their endogeneity with regard to observed and time-constant unobserved heterogeneity. We address these econometric issues by modelling the wage, the employment, and contract decisions in a trivariate random effects model. More precisely, we follow Buchinsky, Fougère, Kramarz, and Tchernis, 2010, (BFKT, hereafter) and use an econometric specification in which the employment decisionin FT work, PT work, or non-employment (NE)—, the type of contract—fixed-term versus permanent—, and the level of wages are jointly determined. The econometric approach gives

\footnotetext{
${ }^{2}$ Alternatively, Hirsch, 2005, uses multiple short panels with two observations per worker (one year apart) to estimate the effect of switching between FT and PT status on wage changes.
} 
rise to three equations estimated simultaneously: (1) a Mincer's wage equation, (2) a reduced form contract-type equation, and (3) a reduced form participation/FT/PT employment equation. The reduced form equations allow for state dependence and duration dependence. In this approach, both experience (in both FT and PT work) and contract type are endogenised with regard to time-constant individual heterogeneity, because they are direct outcomes of the employment and type of contract decisions, respectively. Hence, the model accounts for the potential selection biases that stem from these endogenous decisions. A further advantage of our approach is that we obtain information on the direction and strength of the possible selection based on unobserved heterogeneity. In contrast to BFKT, we have to make the assumption that idiosyncratic errors are independent across equations, because we lack the exclusion restrictions that would allow adding correlation terms for the idiosyncratic errors.

We use Social Security records panel data from 1996 to 2006 from the Spanish Continuous Survey Working History, CSWH hereafter, and estimate the model for all women. Heterogeneity analysis by whether women will become mothers or not is also performed to disentangle the role of PT work as a family-work-reconciling device. To estimate the joint posterior distribution of the model's parameters, we employ Markov Chain Monte Carlo (MCMC) methods.

Empirically, our paper finds the following three results. First, we find that there is a large wage differential of working PT, and that heterogeneity exist by contract type and motherhood status. For example, six years after having worked PT a female worker has an hourly wage that is about $15 \%$ lower than that of a comparable woman who has worked fulltime. The cumulative wage differential is smaller for mothers and larger for childless women working under a permanent contract. This heterogeneity is probably the result of a liberal new Spanish law that grants women with small children the right to request a work-week reduction (with a proportional reduction in their salary) and protects those with a permanent 
contract against dismissal. A second important finding of this paper is that the PT/FT hourly wage differential persists even after many years of having resumed full-time work, especially in the case of women without children. This persistence ought to raise concerns about the long lasting consequences of PT work for women's careers. Finally, our results show the need to explicitly control for past experience in different work arrangements when attempting to estimate the effects across different contract types. We find that the magnitude of the estimated returns changes markedly when we account for this factor, indicating that the PT employment history as well as interruptions during the course of one's career are important for workers’ wage trajectory.

This paper is closer to Connolly and Gregory, 2009, in that it examines the implications of switching to PT work for women's subsequent earnings trajectories; and to Fernández-Kranz and Rodríguez-Planas (forthcoming) in that it analyzes the PT/FT wage differential within two groups of workers, those with and without a permanent contract. Methodologically, our paper contributes to the literature in at least five ways. First, we consider the joint determination of the two most important forms of flexible work: PT work and fixed-term contracts. This is important if the selection into one form of flexible work depends on the experience in the other. Second, we take into account individual heterogeneity, differences in work histories, and endogeneity of the work history, the current work arrangement, and employment with regard to time-constant unobserved heterogeneity. Third, we account for history in a flexible way, which is crucial if the effects of working in a particular state persist across time. Fourth, we disentangle not only the current but also the cumulative wage effects of flexible work arrangements, which give rise to important dynamic aspects of this type of work. Fifth, we are able to distinguish between the wage differential associated with flexible work arrangements and the 'motherhood pay gap' as our analysis is also done separately by motherhood status. 
The remainder of the paper is organised as follows. Section 2 discusses the econometric specification and estimation methodology. Sections 3 and 4 present the data and the empirical results, respectively. Section 5 shows the sensitivity analysis. Concluding remarks are in Section 6.

\section{The Econometric Specification and Estimation}

The model consists of a wage equation and two selection equations: a contract-type equation and an employment-status equation. The wage equation is a linear equation of the log hourly wage implementing a flexible specification for the work history distinguishing FT employment, PT employment, and non-employment, as well as permanent and fixed-term contracts. The contract equation is a dynamic random effects probit equation modelling the probability of a permanent and a fixed-term contract for each period. The employment equation is a dynamic random effects ordered probit equation modelling the decision between NE, PT, and FT. Individual specific random effects in all three equations and their potential correlations across equations serve to capture time-constant unobserved heterogeneity and selection based on it. This is important, as selection based on time-constant unobservables is likely to be an issue and would lead to biased results in a standard (single equation) RE model. $^{3}$ The three-equation model accounts for such—potential—selection effects. Using this approach we also obtain information on the direction and strength of the selection based on unobservables which one would not have obtained when using an approach with a single equation like a standard FE approach.

This approach is methodologically similar to the approach BFKZ use to study the returns to seniority in the U.S. With regard to the idiosyncratic error terms, our model is

\footnotetext{
${ }^{3}$ If, for example, some women are strongly devoted to market work, this unobservable characteristic will, in each period, increase their probability to work full-time and it is also likely to be positively related to the wage obtained, e.g. through being highly productive at work. Another example is that it is likely that having low unobserved "soft skills" will decrease the probability to obtain a permanent contract and also have a negative effect on wages.
} 
more restrictive than their model as we assume independence of the three idiosyncratic error terms. This is a necessary assumption because we need to include a regressor on the current PT status into the wage equation. In this case we could only model dependences between the idiosyncratic errors if we had instruments involving variation over time and over individuals for both selection equations, which we do not have in our data. With regard to the employment equation, we extend the model of BFKZ by introducing PT as a third employment status and then using an ordered probit model for the employment equation.

\section{The Three-Equation Model}

The wage equation is a random effects model of the natural logarithm of the deflated hourly wage of individual $i$ in quarter $t$ on the current PT status, the current contract status (FIX), the work history $\left(\mathrm{H}^{\mathrm{W}}\right)$ and control variables:

$$
\ln \mathrm{W}_{\text {it }}=\beta^{\mathrm{W}}{ }_{0}+\beta^{\mathrm{W}}{ }_{1} \mathrm{PT}_{\mathrm{it}}+\beta^{\mathrm{W}}{ }_{2} \mathrm{FIX}_{\mathrm{it}}+\beta^{\mathrm{W}}{ }_{3} \mathrm{H}^{\mathrm{W}}{ }_{\text {it }}+\beta^{\mathrm{W}}{ }_{4} \mathrm{X}^{\mathrm{W}}{ }_{\text {it }}+\alpha^{\mathrm{W}}{ }_{\mathrm{i}}+\varepsilon^{\mathrm{W}}{ }_{\text {it }}
$$

The way the work history is modelled builds on the specification suggested by Light and Ureta, 1995. ${ }^{4}$ It is summarised by a vector $\mathrm{H}^{\mathrm{W}}$ which collects the employment status and the contract status each quarter from the year before the current period as far back as the sample allows in a very flexible way. This is done by defining an array of dummies for nonemployment (NElag1 to NElag40), for PT employment (PTlag1 to Ptlag40) and for fixedterm contract status (FIXlag1 to FIXlag40). ${ }^{5}$ Such dummies can equal zero for two reasons: (1) if the woman is not in that state in the current year (thus if both the NE and the PT dummy equal zero, the women would be in FT); or (2) if the dummy refers to a year before the individual is observed in the sample. To distinguish these two cases, an array of dummies capturing whether the lag is observed or not is added. We allow for some interactions between contract-type and employment-status. Control variables $\mathrm{x}^{\mathrm{W}}$ include information on

\footnotetext{
${ }^{4}$ Light and Ureta, 1995, use information on the share of weeks worked in each year in their model, but they do not distinguish between PT and FT work and by contract-types.

${ }^{5}$ One concern is that the flexibility of our model leads to multicolinearity, making difficult parameters' identification. To address this, we have re-estimated the model with a less flexible estimation. The results from this less flexible specification were consistent with those presented in the paper.
} 
the individual's age, education, and the age of the youngest child. It also includes information on the region's unemployment rate and GDP growth, as well as the year and the season. For the exact specification of the model see the Appendix Table A.1. ${ }^{6}$

The contract equation is a dynamic random effects probit model of a fixed-term contract dummy on a PT dummy, the work history $\mathrm{H}^{\mathrm{C}}$ and control variables:

$$
\begin{aligned}
& \mathrm{FIX}_{\mathrm{it}}=\mathbf{I}\left(\mathrm{FIX}_{\mathrm{it}}{ }^{*}>0\right) \\
& \mathrm{FIX}_{\mathrm{it}}{ }^{*}=\beta^{\mathrm{C}}{ }_{0}+\beta^{\mathrm{C}}{ }_{1} \mathrm{PT}_{\mathrm{it}}+\beta^{\mathrm{C}}{ }_{2} \mathrm{H}^{\mathrm{C}}{ }_{\mathrm{it}}+\beta^{\mathrm{C}}{ }_{3} \mathrm{X}_{\mathrm{it}}{ }^{\mathrm{C}}+\alpha^{\mathrm{C}}{ }_{\mathrm{i}}+\varepsilon^{\mathrm{C}}{ }_{\mathrm{it}}
\end{aligned}
$$

The vector $\mathrm{H}^{\mathrm{C}}$ and the vector $\mathrm{x}^{\mathrm{C}}$ model the work history and the control variables following the same structure as in the wage equation. As $\mathrm{H}^{\mathrm{C}}$ includes the first lag of the contract-type variable and also earlier lags, the contract-type equation allows for state dependence and duration dependence. Note that the work-history not only includes contract-history but also lagged PT and NE dummies. The wage equation and the contract-type equation are only estimated if the woman is employed in the respective period.

The employment equation is a dynamic random effects ordered probit model of the employment variable E (which equals 2 for FT, 1 for PT and 0 for NE) on the work history $\mathrm{H}^{\mathrm{E}}$ and control variables:

$$
\mathrm{E}_{\mathrm{it}}^{*}=\beta^{\mathrm{E}}{ }_{0}+\beta^{\mathrm{E}}{ }_{1} \mathrm{H}^{\mathrm{E}}{ }_{\mathrm{it}}+\beta^{\mathrm{E}}{ }_{2} \mathrm{X}^{\mathrm{E}}{ }_{\mathrm{it}}+\alpha^{\mathrm{E}}{ }_{\mathrm{i}}+\varepsilon^{\mathrm{E}}{ }_{\mathrm{it}}
$$

where $\mathrm{E}^{*}$ denotes the latent variable. Work history and control variables are modelled following the same concept as in the other equations. Again work history includes the employment-status history as well as the contract-status history and state dependence and duration dependence are allowed for. The initial conditions are modelled as suggested by Wooldridge, 2005; thus the values of the left-hand side variables for the initial period are added to the equations in each period.

\footnotetext{
${ }^{6}$ We do not include information on occupation, industry and seniority among the control variables because these are likely to be outcomes of our regressors of interest (i.e. the employment history).
} 
All three equations include an individual unobserved effect $\alpha^{\mathrm{W}}{ }_{\mathrm{i}}, \alpha^{\mathrm{C}}{ }_{\mathrm{i}}, \alpha^{\mathrm{E}}{ }_{\mathrm{i}}$ and these are assumed to follow a joint normal distribution $\mathrm{N}(0, \Sigma)$ which allows for correlation among them. The current employment status, the current contract-type, experience in FT and PT work, as well as experience in a specific contract type are endogenised with regard to timeconstant unobserved characteristics. The idiosyncratic errors are assumed to be independently normal distributed: $\varepsilon^{\mathrm{W}}{ }_{\text {it }} \sim \mathrm{N}\left(0, \sigma^{2}\right), \varepsilon^{\mathrm{C}}{ }_{\text {it }} \sim \mathrm{N}(0,1), \varepsilon^{\mathrm{E}}{ }_{\text {it }} \sim \mathrm{N}(0,1)$.

\section{Identification}

Identification of this model depends on functional form restrictions and time-varying covariates (Hyslop, 1999). Identification could be supported by exclusion restrictions but in a dynamic context it is particularly difficult to find suitable exclusion restrictions because the variable or its effect has to change with the individual and with the time period (see for example Heckman and Navarro, 2007). This problem is not uncommon in this literature, and it is often addressed by using children and marital status as instruments—see Ermisch and Wright, 1993; Blank, 1998; Manning and Petrongolo, 2008, among others- . However, it is well established that "this is a very strong assumption that may not, in reality, be any better than the exogeneity assumption that this is supposed to replace” (Manning and Petrongolo, page F33, Economic Journal 2008). Aaronson and French, 2004, are the only ones that we know of to use an alternative instrument for worked hours, the work disincentive of the US Social Security system. They are able to isolate exogenous shifts into PT employment resulting from changes in Social Security rules for older men and women.

Note that in our model identification comes from both the cross-sectional and the time-series dimensions, while a FE approach only uses the time series dimension for identification (“within identification”). One of the advantages of our data set is its size, which is much larger (in terms of observations and years) than what is standard in the literature. This is important because it adds sufficient time-series variation to support identification as many women switch between states during the sample period. Moreover, 
the sizeable cross-sectional dimension facilitates the use of differences between women who follow distinct sequences of employment decisions over their working life. To use crosssectional identification along with time-series identification increases the efficiency of the estimator. This may be important in particular if a very flexible specification with history effects is used (e.g. modelling different forms of work arrangements in all periods).

\section{Estimation}

To estimate the model, we use Bayesian Markov Chain Monte Carlo (MCMC) techniques. This approach avoids simulating integrals and allows a numerically robust estimation of the flexible model specification. The goal of this technique is to obtain a sample from the posterior distribution of the model parameters. From a classical perspective, the mean of the posterior distribution converges to the point estimator from maximum likelihood estimation and the variance of the posterior distribution converges to the asymptotic variance of the point estimator in maximum likelihood estimation. Thus, the mean of the draws may be interpreted as the coefficient and the standard deviation as standard errors. ${ }^{7}$ Conjugate but very diffuse priors are used. We obtain a sample of the posterior distribution of our model parameters by running 50,000 iterations of a Gibbs sampling algorithm. We monitor convergence by comparing the means at different stages of the chains. The first 10,000 iterations are discarded (the burn-in phase). We implemented the Gibbs sampler in Stata.

The analysis is first done for the whole sample, and then separately for whether women become mothers at some point in time or are childless women. ${ }^{8}$ The heterogeneity analysis by motherhood status responds to two things. First, many mothers chose PT work as a means of reconciling family life and work, and thus, we want to disentangle how much this motivation for PT work is driving our results. Second, the Spanish legislation gives the right

\footnotetext{
${ }^{7}$ See Chib, 2008, for a survey of MCMC methods for Panel data and Train, 2003, for an overview over important properties of MCMC estimators. Recent applications in labour economics are BFKT, Fitzenberger et. al., 2010, Horny et al., 2009, and Troske and Voicu, 2010.

${ }^{8}$ To remain childless may be a decision which is influenced by the individual's labour market outcome and thus the sample separation might be to some extend endogeneous, but we think that for an additional heterogeneity analysis this is not too problematic.
} 
to request a work-week reduction (with a proportional reduction in their salary) to mothers with small children (under 7 years old) and protects them against dismissal if they use this right while working under a permanent contract (see Fernández-Kranz and Rodríguez-Planas, 2011, for an analysis of the effects of such policy).

\section{Data and Descriptive Statistics}

We use data from the 2006 wave of the Continuous Sample of Working Histories (hereafter $\mathrm{CSWH})$, which is a $4 \%$ non-stratified random sample of the population registered with the Social Security Administration in 2006 and provides the complete labour market history of the selected individuals back to 1967. It provides information on: (1) socio-demographic characteristics of the worker (such as, sex, education, nationality, province of residence, number of children in the household and their date of birth); and (2) worker's job information (such as type of contract, PT status, occupation, the dates the employment spell started and ended, and monthly earnings). Although not reported in the CSWH, other variables such as experience (in FT and PT work) and tenure can be easily calculated. Because the CSWH does not have reliable information on type of contract prior to 1996, our analysis focuses on the years 1996 to 2006. However, we use information back to 1985 to calculate variables such as workers’ initial experience.

We focus our analysis on wage and salary workers, that is, we exclude from the analysis self-employed individuals. We confine our selection to birth cohorts between 1961 and 1978. In addition, we restrict women in our sample to be aged between 24 and 45 years. The reason for dropping women younger than 24 years old is that we want to eliminate PT work by students - a standard restriction in the literature. Finally, because we want to 
confine the analysis to women with a strong attachment to the labour force, we further restrict our sample to women who record at least three years in FT employment. ${ }^{9}$

This sample selection results in an unbalanced panel of 427,254 observations on 15,138 women, of which 2,157 (14.25\%) are observed working PT at some point in time between 1996 and 2006, and 28\% are observed working under a fixed-term contract in a least one period. Following most of the European literature, we classify a worker working PT if she works 30 hours or less each week, and FT if she works 31 or more hours each week. We observe on average 34 quarters in our sample of analysis.

Pooling all periods together, $88 \%$ of the women in our sample work FT under permanent contracts, 7.7\% work FT under a fixed-term contract, 3.4\% work PT under a permanent contract, and 1.3\% work PT under fixed-term contract (shown in first row of Table 1). ${ }^{10}$ Together with the fact that an important number of women experiences employment in a flexible labour market state at least once during the sample period (see above), this indicates that we observe a considerable number of switches between employment arrangements in our data. While the average number of years of experience in the estimation sample in a given period is 5.43, Table 1 shows that the average experience in each of the four states (FT Permanent, PT Permanent, FT Fixed-term, PT Fixed-term) varies considerably with the current PT/FT status and current type of contract. ${ }^{11}$ For instance, the average number of years of FT work experience in a permanent contract drops from 5 to 1.7 years if the worker works FT but under different type of contracts. These descriptive statistics suggest that women working under fixed-term contracts have very different labour market histories than those working under permanent contracts, not only with regard to past contract states but also with regard the past PT states.

\footnotetext{
${ }^{9}$ Furthermore, we restrict our sample to women who are observed for at least four quarters. Finally, we do not use the first year for our estimation but just for the construction of the state dependence variables.

${ }^{10}$ For a compact presentation, we use years in our tables, but we obtain the results based on a panel data set in quarters.

${ }^{11}$ Although one individual can appear under different categories in different waves of the panel, it should be noted that these four categories are mutually exclusive.
} 
Table 2 presents descriptive statistics of key variables, again by PT status and contract type. Comparison of the (raw) hourly wages indicates that the highest wages are paid in standard work arrangements (FT under a permanent contract), and that they are lower for more flexible work arrangements with the greatest reduction being associated with working PT under a fixed-term contract. ${ }^{12}$ Table 3 depicts means of key variable by motherhood status. Both states involving PT work are less frequent among childless women. In contrast, the opposite is true for working FT under fixed-term contracts, which is a more frequent among the childless than in the whole sample. With regard to the other variables the picture is quite similar to the one observed for the whole sample.

\section{Results}

Tables A.1 displays means and standard deviations of the posterior distribution of the model parameters that can be interpreted as coefficients and standard errors from a Maximum Likelihood estimation. However, for ease of interpretation, we focus our discussion on the cumulative effects of different employment states shown in Table 4. Before we proceed to discuss the results, it is worth highlighting that, in contrast with the literature, which focuses on PT/FT wage differentials by type of contract, we compare the effects to the reference situation of working FT in a permanent contract, as this is the most common employment situation in Spain and our econometric approach allows us to do so.

\section{Wage Differentials due to First Quarter Work Arrangement}

\footnotetext{
${ }^{12}$ Our measure of pay is hourly earnings, calculated as annual earnings excluding overtime divided by total contractual hours, deflated by the 2006 price deflator. Because our data set collects information on contractual annual hours (as opposed to actual annual hours worked), we follow Fernández-Kranz and Rodríguez-Planas (forthcoming) to impute effective hours worked as follows. First, using the Spanish Time Use Survey, we regressed hours worked against contractual hours, a part-time dummy, age, education, two-digit industry dummies and occupation dummies (estimates available from authors upon request). Then, using these estimated coefficients, we calculated fitted hours worked for the women in our CSWH sample. The concern here is that contractual hours consistently underreport actual hours worked for PT workers relative to FT workers, leading to a differential measurement error in hours by PT status. Fernández-Kranz and Rodríguez-Planas (forthcoming) show that by imputing effective hours worked in the explained way this concern is addressed.
} 
The first column of Table 4 presents the estimated marginal effects of having worked in a particular employment state for one quarter, as well as the period's returns to experience (relative to the baseline state, which is working FT with a permanent contract). Thus it gives our ceteris paribus estimates of the wage effect of the first quarter employment situation in a particular employment state given the employment history.

The results from Panel A indicate a large and significant PT/FT hourly wage gap ranging between 6 and 8 percentage points. This gap can be interpreted as a quick drop in wages associated with PT work. Interestingly, this wage differential is almost as large for women working under a fixed-term contract than for those under a permanent contract, suggesting that, on average, having a permanent contract does not protect women against the negative wage effects of PT work. Likely reasons for wages growing less in PT jobs are that working in these jobs may involve less training, less possibilities to reach managerial positions and fewer chances to stand out by managing projects or doing extra work. Our econometric model allows for the possibility that the wage effect of PT under fixed-term contracts is not just the combination of PT under a permanent contract and FT under a fixedterm contract but that PT under a fixed-term contract involves its own - potentially different wage effect. It turns out that the effect of PT under a fixed-term contract does not differ strongly from the effect of PT under a permanent contract, but differs a lot from the wage effect of FT under a fixed-term contract. If we compare the PT/FT wage differential within contract types, we find a higher PT/FT wage differential among fixed-term workers than among permanent workers, as found by Fernández-Kranz and Rodríguez-Planas (forthcoming).

Looking at the wage effect of having worked FT under a fixed-term contract for a quarter, we find that there is a small wage premium of currently working under a fixed-term contract (shown in the third row in Panel A, Table 4). Following the theory of compensating wage differences, this small premium might reflect some compensation for less job security 
and potentially less job related benefits (see Booth et al., 2002). It is, however, worth highlighting that this fixed-term-contract premium is conditional on the complete history. Thus, given that those women with a more disadvantaged history are those who select into fixed-term contracts, this small premium does in no way contradict that wages are, on average, lower in the secondary segment of the labour market than in the primary (as found by Blanchard and Landier, 2002; Booth et al., 2002; Dolado, et al., 2002, and De la Rica, 2004, among others).

Because average effects may hide important differences across groups, column 1 of Panels B and C presents similar results estimated separately by motherhood status. We find that heterogeneity exists. Indeed, the PT/FT hourly wage differential for childless women working under a permanent contract doubles that of mothers. However, the opposite is true for women working under a fixed-term contract. The reason behind the smaller wage gap among mothers working under a permanent contract is likely to be related to a novel and liberal Spanish law implemented in 1999 that granted mothers with children under seven the right to reduce their work-week schedule (with a proportionate reduction in their weekly salary), and (most importantly) protected them against dismissal. While this law was binding among women with permanent contracts, it was not among those with fixed-term contracts as employers only had to wait for the contract to expire to let them go. Fernández-Kranz and Rodríguez-Planas, 2011, find evidence corroborating this asymmetry in the effectiveness of the law.

\section{Cumulative Returns to PT Work}

We turn now to the results of the cumulative effects of PT work. The parameter estimates of the wage equation with regard to employment status and contract-type in the past (shown in Table A.1) answer the question of how much it harms to have worked in a particular situation in the past (irrespective of the current work situation). Summing up these marginal effects one can come up with estimates of the cumulative effects of having worked in PT during a 
given number of quarters, or years. For ease of exposure, this is what is shown in columns 2 through 9 of Table 4. For example, the value in column 5 indicates the cumulative wage effect of having worked PT during the past two years. Technically, the cumulative effects and their standard errors are obtained by obtaining a draw of the posterior distribution of the cumulative effect of interest for each iteration of the Gibbs sampler and then estimating from the resulting draws their mean and standard deviation. As such the cumulative returns to working two years PT in a fixed-term contract is calculated by adding up the draws of the model parameter for working PT and in a fixed-term PT contract in the current quarter and in the last eight quarters.

Two important conclusions emerge from these results. First, the negative wage return due to PT work grows with each additional quarter or year in PT work. This clearly indicates that the returns to experience in PT work are lower than in FT work, regardless of contract type. Because these estimates come from adding the parameters for working PT in the past, these results also imply that the PT wage gap is persistent across time. For example, having worked PT under a permanent contract four years ago carries a negative wage return for current wages of $1.3 \%{ }^{13}$ This persistence implies that even short and temporary spells of PT work will have long lasting negative consequences for a woman’s labour career.

Second, the results indicate that the cumulative effects of PT work under a permanent contract grow faster for childless women than for women with children. For example, after six years of continuous PT work, the PT/FT wage gap has widen to 25 percent in the case of childless women compared to 13 percent in the case of women with children. This larger wage effect indicates that working PT under a permanent contract leads to particularly low returns to experience for women without family responsibilities.

Another advantage of our methodological approach is that we can also evaluate the wage effects of intermittent labour behaviour. The last rows of Panels A through C in Table

\footnotetext{
${ }^{13}$ The marginal returns are available from the authors upon request.
} 
4 show the negative wage return of non-employment in the past. As one would expect, a history of non-employment has worse wage consequences than working PT. For example, having interrupted employment for the last year goes along with a wage differential of $15 \%$ (relative to permanent FT work). This wage gap further increases to 35\% after an interruption of six years. These results put the PT/FT hourly wage differential into perspective. While it is true that, on the one hand, experience in PT work is less rewarded than in FT work; on the other hand, the effects are not as detrimental on women's wages as interrupting employment.

\section{Variance and Covariance Parameters}

Table 5 shows means and standard deviations of the posterior distribution of the variance parameters. The estimated variance parameters suggest that an important part of the variance is on the individual level in all three equations, indicating that time-constant unobserved heterogeneity is important, especially in the wage equation (where it represents 83\%). While this ratio is somewhat lower for the contract equation (23\%) and the employment equation (33\%), they are far from insignificant. The positive correlation between the unobserved individual effect of the wage equation and the employment equation suggests that, with regard to time-constant unobservables, those women who have unobservables leading to higher wages also tend to have unobservables leading to a higher employment propensity. Consistent with this, the negative correlation of the unobserved individual effect of the wage equation and the contract equation indicates that the unobserved individual characteristics that lead to a higher propensity to have a fixed-term contract tend to go along with those characteristics that give rise to lower wages. Finally, the individual correlation between the employment equation and the contract equation is also negative, indicating that those timeconstant unobserved individual characteristics that lead to a higher propensity to have a fixed-term contract tend to go along with those characteristics that lead to a lower employment propensity. Bottom line, our results support the view that those women with unobservable characteristics favourable to market work tend to work under permanent 
contracts and in FT jobs. All variance and covariance parameter are significant. Given the size and significance of the covariance parameters, the estimation results confirm that the heterogeneity on the individual level should not be neglected. The subgroup analysis reveals similar results.

\section{Sensitivity Analysis}

Sensitivity analysis is shown in Table 6 and indicates that our results are remarkably robust to using more standard methods. Moreover, it also highlights that it is crucial to account for the history with regard to PT, FT and NE and with regard to contracts and interdependencies of these. Finally, we confirm that individual heterogeneity must be taken into account.

Assuming independence of: the work history, the current employment, and contract status, with individual's time-constant unobserved heterogeneity-as it is assumed in the standard RE model with one equation-is incorrect because we have found strong and significant correlations between the random effects of the three equations in the variancecovariance matrix. Thus, it may come as a surprise that the standard RE model (with one instead of our three equations and shown in Panel A of Table 6) delivers similar results to those presented in the main section of the paper. The explanation for this is not that the assumptions of the standard RE model are fulfilled, but instead that the different correlations work in opposite directions, partially cancelling out. Economically this means that the size of the positive unobserved selection into FT employment and the size of the negative selection into fixed-term contracts, given the link between them, state dependence, and observed characteristics, are such in our data that they partly offset each other. If and to what extent this happens cannot be anticipated ex-ante and may differ in other settings, thus by no means depreciating our technique. 
Alternatively, we have compared our results with those from using a FE approach (shown in Panel B of Table 6). A FE estimator solely relies on within identification which may be a drawback especially when estimating a very flexible specification (as we do in this paper), and when observing only a small part of the woman’s work history. It turns out that sample size is sufficiently large and our panel is sufficiently long, that the FE estimator performs quite well in replicating our results. Finally, we use pooled OLS to estimate our wage equation (see Panel C). POLS results are strongly biased delivering large PT/FT wage differentials. If anything, these results confirm the importance of accounting for unobserved individual heterogeneity when estimating the PT wage differential. Regarding the effect of working FT in a fixed-term contract, the POLS estimation shows large cumulative negative returns to this type of work due to neglecting unobserved heterogeneity. That said, note that even POLS estimation does not suggest a (strong) negative first quarter effect of working FT under a fixed-term contract. As an additional robustness check, we re-estimated the wage equation by POLS excluding the labour market history, and we found an hourly wage gap for working under a fixed-term contract of $16 \%$. This exercise highlights the importance of including the employment history with regard to NE, PT, and FT and the contract-history and interactions of these when estimating the wage effects of contract-types. ${ }^{14}$ Moreover, it indicates that a large part of the apparent fixed-term wage gap seems to be driven by the different work experience of women in the primary and in the secondary segments of the labour market.

Finally, we checked whether adding industry dummies, occupation dummies and seniority on the job to the wage equation influences our results. As mentioned before, we did not include these variables into the wage equation because they may be outcomes to experience in different work arrangements. As a sensitivity exercise, we re-estimated the

\footnotetext{
${ }^{14}$ A FE estimator of a wage equation without history and PT controls indicates a return to working under a fixed-term contract of $-3.6 \%$; thus part of the history effect is captured by time-constant unobserved heterogeneity.
} 
wage equation with different specification choices including industry and occupation dummies, and a variable measuring elapsed seniority on the job. To make this exercise feasible, we used both the standard FE and the RE estimators. Again, the results are robust to the main findings of the paper.

\section{Conclusion}

In this study we use Spanish Social Security records to examine the wage differences between PT and full-time female workers. Employing a three-equation RE model, we use a different methodological approach than the previous literature which offers new perspectives. We follow BFKZ, 2010, and explicitly model the participation/employment and PT status and type of contract mobility decisions, which, in turn, define the individual's experience in different segments of the labour market. We introduce into the wage equation a summary of the workers' entire observed career path. The three-equation system is estimated simultaneously using data from Spanish Social Security records and MCMC estimation.

Our results indicate that there is a large and persistent FT/PT hourly wage differential. Having a permanent contract protects against the PT wage gap only partially and only for mothers. Importantly, our results show that work experience is rewarded less in PT work than in full-time work and these (low) returns are quite similarly low in the two segments of the labour market.

Also, our results highlight the importance of controlling for work history in this type of studies. More precisely, we find that part of the PT/FT wage differential can be explained by differential employment histories of PT and full-time workers. This is important not only for the estimation of the PT wage differential but also for the estimation of the wage effects of other types of flexible work. For example, after controlling for work history, we find that there is no negative wage return for working under fixed-term contracts. 
The persistence of the negative effects of PT work draws a bleak picture for rigid labour markets where this type of work arrangement is often presented as an alternative to add flexibility and to reduce the high levels of unemployment. Furthermore, our results imply that work-family conciliation through work-week reduction carries a significant negative wage return, one that extends beyond the period during which the worker has been working PT.

\section{REFERENCES}

Aaronson, D., and E. French. (2004). "The Effect of Part-Time Work on Wages: Evidence from the Social Security Rules”, Journal of Labor Economics, vol. 22, No. 2 (April), pp. 329-352.

Bentolila, S., P. Cahuc, J. Dolado and T. Le Barbanchon (2010). “Two-Tier Labor Markets in the Great Recession: France vs. Spain”, IZA Discussion Paper No. 5340, Bonn.

Blanchard O. and A. Landier (2002). "The Perverse Effects of Partial Labor Market Reform: Fixed Duration Contracts in France.” Economic Journal, vol. 112(480), pp. F214-F244.

Blank, R. (1998). "Labour Market Dynamics and Part-Time Work", in Solomon W. Polacheck (ed.), Research in Labour Economics, vol. 17, JAI Press, Stamford, Connecticut.

Buchinsky, M. , D. Fougère, F. Kramarz and R. Tchernis (2010). "Interfirm Mobility, Wages, and the Returns to Seniority and Experience in the U.S." Review of Economic Studies, vol. 77, pp. 972-1001.

Booth, A., Francesconi, M. and Frank, J. (2002). 'Temporary jobs: stepping stones or deadends?’ Economic Journal, vol. 112(480), pp. F189-213.

Booth A., and M. Wood. (2008). "Back-to-Front Down Under? PT/ FT Wage Differentials in Australia.” Industrial Relations, vol. 47, No. 1, pp. 114-135.

Chib S. (2008). "Panel Data Modeling and Inference: a Bayesian Primer." In L. Matyas and P. Sevestre (eds.): The Econometrics of Panel Data, Fundamentals and Recent Developments in Theory and Practice, 3. edition, Berlin: Springer 2008, pp. 479-516.

Connolly, S. and M. Gregory. (2009). "The PT Pay Penalty: Earnings Trajectories of British Women.” Oxford Economic Papers, vol. 61 no. S1, pp. 76-97.

De la Rica, S. (2004). "Wage Gaps between Workers with Indefinite and Fixed-Term Contracts: The Impact of Firm and Occupational Segregation." Moneda y Crédito vol. 219, pp. 43-69. 
Dolado, J., C. García-Serrano and J.F. Jimeno. (2002). "Drawing Lessons from the Boom of Temporary Jobs in Spain,” Economic Journal, vol. 112(480), pp.F270-295.

Ermisch, J., and R. Wright. (1993). "Wage offers and full-time and part-time employment by British women.” Journal of Human Resources, vol. 28 (Winter), pp. 111-33.

Fernández-Kranz, D and N. Rodriguez-Planas. “The PT Pay Penalty in a Segmented Labour Market.” Labour Economics (forthcoming).

Fernández-Kranz, D and N. Rodriguez-Planas. (2011). "Unintended Effects of a FamilyFriendly Law.” IZA discussion paper No. 5709, May, 2011, Bonn.

Fitzenberger, B., A. Osikominu and M. Paul (2010). “The Heterogeneous Effects of Training Incidence and Duration on Labour Market Transitions”, IZA Discussion Paper No. 5269, Bonn.

Heckman, J.J. and S. Navarro (2006). "Dynamic Discrete Choice and Dynamic Treatment Effects.” Journal of Econometrics, vol. 136, pp. 341-396.

Hirsch, B. (2005). "Why Do PT Workers Earn Less? The Role of Worker and Job Skills.” Industrial and Labour Relations Review, vol. 58 (July). pp. 525-51.

Horny, G., R. Mendes and G. J. van den Berg (2009). "Job Durations and Firm Specific Effects: MCMC Estimation with Longitudinal Employer-Employee Data.” IZA Discussion Paper No. 3992, Bonn.

Hyslop, D.R. (1999). "State Dependence, Serial Correlation and Heterogeneity in Intertemporal Labour Force Participation of Married Women.” Econometrica, vol. 67, pp.1255-1294.

Jimeno, J.F. and L. Toharia. (1993). "The Effects of Fixed-Term Employment on Wages: Theory and Evidence from Spain,” Investigaciones Económicas, vol. 17(3), pp. 475-494.

Light A. and M. Ureta (1995). “Early-Career Work Experience and Gender Wage Differentials” Journal of Labour Economics 3, pp. 121-154.

Manning, A. and B. Petrongolo. (2008). "The PT Pay Penalty for Women in Britain.” Economic Journal, vol. 118, pp. F28-51.

Train, K. (2003). “Discrete Choice Methods with Simulation.“ Cambridge: Cambridge University Press.

Troske, K.R. and A. Voicu (2010). "Joint estimation of sequential labour force and fertility decisions using Markov Chain Monte Carlo techniques. “ Labour Economics vol. 17. pp.150-169.

Wooldridge J.M. (2005). "Simple solutions to the initial conditions problem in dynamic, nonlinear panel data models with unobserved heterogeneity.” Journal

of Applied Econometrics vol. 20, pp. 39 - 54. 
Table 1

Experience in Different Employment States. 1996-2006 CSWH Pooled Sample (Means with Standard Deviations in Parentheses)

\begin{tabular}{|l|c|c|c|c|}
\hline & FT, Permanent & PT, Permanent & FT, Fixed-term & PT, Fixed-term \\
\hline $\begin{array}{l}\text { Dummy for respective employment } \\
\text { status in t }\end{array}$ & $0.876(0.329)$ & $0.0341(0.181)$ & $0.077(0.267)$ & $0.013(0.111)$ \\
\hline $\begin{array}{l}\text { Years of experience in FT, } \\
\text { Permanent observed since initial } \\
\text { period of sample }\end{array}$ & $5.011(2.812)$ & $4.137(2.617)$ & $1.668(2.230)$ & $2.597(2.548)$ \\
\hline $\begin{array}{l}\text { Years of experience in PT, } \\
\text { Permanent observed since initial } \\
\text { period of sample }\end{array}$ & $0.020(0.242)$ & $2.063(1.862)$ & $0.022(0.241)$ & $0.074(0.433)$ \\
\hline $\begin{array}{l}\text { Years of experience in FT, Fixed- } \\
\text { term observed since initial period of } \\
\text { sample }\end{array}$ & $0.104(0.576)$ & $0.227(0.914)$ & $2.457(2.379)$ & $0.381(0.965)$ \\
\hline $\begin{array}{l}\text { Years of experience in PT, Fixed- } \\
\text { term observed since initial period of } \\
\text { sample }\end{array}$ & $0.016(0.206)$ & $0.231(0.774)$ & $0.048(0.312)$ & $1.787(2.104)$ \\
\hline $\begin{array}{l}\text { Years of FT experience in initial } \\
\text { period }\end{array}$ & $7.326(3.774)$ & $6.595(3.268)$ & $4.848(2.613)$ & $5.630(3.020)$ \\
\hline $\begin{array}{l}\text { Years of PT experience in initial } \\
\text { period }\end{array}$ & $0.171(0.602)$ & $0.503(1.038)$ & $0.210(0.576)$ & $1.004(1.409)$ \\
\hline
\end{tabular}

Note: For a compact presentation, we use years in our tables, but we obtain the results based on a panel data set in quarters.

Table 2

Descriptive Statistics. 1996-2006 CSWH Pooled Sample (Means with Standard Deviations in Parentheses)

\begin{tabular}{|c|c|c|c|c|}
\hline & FT, Permanent & PT, Permanent & FT, Fixed-term & PT, Fixed-term \\
\hline Log hourly wage & $2.386(0.409)$ & $2.046(0.457)$ & $2.277(0.462)$ & $1.806(0.577)$ \\
\hline Hourly wage in Euro & $11.766(4.538)$ & $8.623(4.485)$ & $11.065(11.266)$ & $7.443(7.067)$ \\
\hline Age from 23 to 29 & $0.072(0.258)$ & $0.013(0.115)$ & $0.102(0.302)$ & $0.028(0.166)$ \\
\hline Age from 30 to 34 & $0.315(0.465)$ & $0.271(0.444)$ & $0.389(0.488)$ & $0.219(0.413)$ \\
\hline Age from 35 to 39 & $0.393(0.488)$ & $0.447(0.497)$ & $0.309(0.462)$ & $0.429(0.495)$ \\
\hline Age from 40 to 45 & $0.219(0.414)$ & $0.269(0.443)$ & $0.120(0.340)$ & $0.324(0.468)$ \\
\hline Less than secondary education & $0.322(0.467)$ & $0.455(0.498)$ & $0.315(0.465)$ & $0.599(0.490)$ \\
\hline Secondary education & $0.410(0.492)$ & $0.379(0.485)$ & $0.230(0.458)$ & $0.269(0.444)$ \\
\hline More than secondary education & $0.268(0.443)$ & $0.166(0.372)$ & $0.385(0.487)$ & $0.132(0.338)$ \\
\hline No child & $0.486(0.500)$ & $0.251(0.434)$ & $0.582(0.493)$ & $0.342(0.474)$ \\
\hline Youngest child younger than 2 years & $0.155(0.362)$ & $0.309(0.462)$ & $0.123(0.328)$ & $0.123(0.329)$ \\
\hline Youngest child 3 years & $0.046(0.209)$ & $0.084(0.277)$ & $0.031(0.173)$ & $0.043(0.202)$ \\
\hline Youngest child 4 to 6 years & $0.112(0.315)$ & $0.142(0.349)$ & $0.073(0.259)$ & $0.114(0.318)$ \\
\hline Youngest child 7 to 29 years & $0.202(0.401)$ & $0.214(0.450)$ & $0.192(0.394)$ & $0.379(0.485)$ \\
\hline
\end{tabular}


Table 3

Key Descriptive Statistics by Motherhood Status (Means with Standard Deviations in Parentheses)

\begin{tabular}{|c|c|c|c|c|}
\hline \multicolumn{7}{|c|}{ Panel A: Mothers (to be) } \\
\hline & FT, Permanent & PT, Permanent & FT, Fixed-term & PT, Fixed-term \\
\hline Dummy of status in t & $0.875(0.330)$ & $0.042(0.202)$ & $0.068(0.251)$ & $0.014(0.119)$ \\
\hline Raw wage in Euro & $11.81(4.55)$ & $8.68(4.50)$ & $10.47(8.38)$ & $7.24(6.96)$ \\
\hline University degree & $0.254(0.435)$ & $0.162(0.369)$ & $0.310(0.462)$ & $0.114(0.318)$ \\
\hline Less than secondary school & $0.340(0.474)$ & $0.447(0.497)$ & $0.397(0.489)$ & $0.627(0.484)$ \\
\hline $\begin{array}{l}\text { Years of experience in FT, Permanent } \\
\text { observed since initial period of sample }\end{array}$ & $5.083(2.813)$ & $4.145(2.648)$ & $1.791(2.340)$ & $2.456(2.549)$ \\
\hline \multicolumn{5}{|c|}{ Panel B: Childless Women } \\
\hline & FT, Permanent & PT, Permanent & FT, Fixed-term & PT, Fixed-term \\
\hline \multicolumn{7}{|c|}{$0.877(0.328)$} & $0.021(0.143)$ & $0.092(0.289)$ & $0.009(0.097)$ \\
\hline Dummy of status in t & $11.70(4.53)$ & $8.43(4.44)$ & $11.75(13.87)$ & $7.94(7.29)$ \\
\hline Raw wage in Euro & $0.290(0.454)$ & $0.180(0.384)$ & $0.473(0.499)$ & $0.175(0.380)$ \\
\hline University degree & $0.293(0.455)$ & $0.481(0.450)$ & $0.219(0.414)$ & $0.531(0.499)$ \\
\hline $\begin{array}{l}\text { Years of experience in FT, Permanent } \\
\text { observed since initial period of sample }\end{array}$ & $4.897(2.806)$ & $4.110(2.525)$ & $1.525(2.009)$ & $2.935(2.512)$ \\
\hline
\end{tabular}

Table 4

Estimated Cumulative Returns to a Particular Labour Force State (Reference Category: FT Work under a Permanent Contract)

\begin{tabular}{|c|c|c|c|c|c|c|c|c|c|}
\hline \multicolumn{10}{|c|}{ Panel A: All Women } \\
\hline \multicolumn{10}{|c|}{ Quarters / Years in that state } \\
\hline & Q1 & Q2 & Q3 & Q4 & Y2 & Y3 & Y4 & Y5 & Y6 \\
\hline $\begin{array}{c}\text { PT fixed- } \\
\text { term }\end{array}$ & $\begin{array}{l}-7.951 \\
(0.428)\end{array}$ & $\begin{array}{l}-9.826 \\
(0.431)\end{array}$ & $\begin{array}{l}-11.413 \\
(0.450)\end{array}$ & $\begin{array}{l}-12.844 \\
(0.459)\end{array}$ & $\begin{array}{c}-13.659 \\
(0.496)\end{array}$ & $\begin{array}{l}-13.434 \\
(0.532)\end{array}$ & $\begin{array}{l}-14.887 \\
(0.542)\end{array}$ & $\begin{array}{l}-15.716 \\
(0.558)\end{array}$ & $\begin{array}{l}-16.545 \\
(0.602)\end{array}$ \\
\hline $\begin{array}{c}\text { PT } \\
\text { Permanent }\end{array}$ & $\begin{array}{l}-6.197 \\
(0.340)\end{array}$ & $\begin{array}{l}-8.428 \\
(0.325)\end{array}$ & $\begin{array}{l}-10.370 \\
(0.330)\end{array}$ & $\begin{array}{l}-12.158 \\
(0.305)\end{array}$ & $\begin{array}{l}-12.942 \\
(0.302)\end{array}$ & $\begin{array}{l}-12.591 \\
(0.342)\end{array}$ & $\begin{array}{l}-13.917 \\
(0.341)\end{array}$ & $\begin{array}{l}-14.620 \\
(0.326)\end{array}$ & $\begin{array}{l}-15.324 \\
(0.358)\end{array}$ \\
\hline $\begin{array}{l}\text { FT fixed- } \\
\text { term }\end{array}$ & $\begin{array}{l}1.181 \\
(0.217)\end{array}$ & $\begin{array}{l}1.230 \\
(0.189)\end{array}$ & $\begin{array}{l}1.280 \\
(0.196)\end{array}$ & $\begin{array}{l}1.330 \\
(0.235)\end{array}$ & $\begin{array}{l}1.300 \\
(0.247)\end{array}$ & $\begin{array}{l}1.173 \\
(0.261)\end{array}$ & $\begin{array}{l}1.047 \\
(0.284)\end{array}$ & $\begin{array}{l}0.921 \\
(0.313)\end{array}$ & $\begin{array}{l}0.795 \\
(0.348)\end{array}$ \\
\hline $\mathrm{NE}$ & $\begin{array}{l}-3.100 \\
(0.319)\end{array}$ & $\begin{array}{l}-6.668 \\
(0.332) \\
\end{array}$ & $\begin{array}{l}-9.707 \\
(0.343) \\
\end{array}$ & $\begin{array}{l}-14.897 \\
(0.331) \\
\end{array}$ & $\begin{array}{l}-22.926 \\
(0.362) \\
\end{array}$ & $\begin{array}{l}-27.781 \\
(0.396) \\
\end{array}$ & $\begin{array}{l}-33.242 \\
(0.426) \\
\end{array}$ & $\begin{array}{l}-33.864 \\
(0.464) \\
\end{array}$ & $\begin{array}{l}-34.486 \\
(0.534) \\
\end{array}$ \\
\hline \multicolumn{10}{|c|}{ Panel B: Mothers (to be) } \\
\hline \multicolumn{10}{|c|}{ Quarters / Years in that state } \\
\hline & Q1 & Q2 & Q3 & Q4 & Y2 & Y3 & Y4 & Y5 & Y6 \\
\hline $\begin{array}{l}\text { PT fixed- } \\
\text { term }\end{array}$ & $\begin{array}{l}-9.353 \\
(0.542)\end{array}$ & $\begin{array}{l}-11.599 \\
(0.537)\end{array}$ & $\begin{array}{l}-12.818 \\
(0.552)\end{array}$ & $\begin{array}{l}-13.699 \\
(0.568)\end{array}$ & $\begin{array}{l}-15.169 \\
(0.605)\end{array}$ & $\begin{array}{l}-14.737 \\
(0.651)\end{array}$ & $\begin{array}{l}-15.056 \\
(0.663)\end{array}$ & $\begin{array}{l}-15.563 \\
(0.690)\end{array}$ & $\begin{array}{l}-16.070 \\
(0.745)\end{array}$ \\
\hline $\begin{array}{c}\text { PT } \\
\text { Permanent }\end{array}$ & $\begin{array}{l}-5.169 \\
(0.402)\end{array}$ & $\begin{array}{l}-7.750 \\
(0.391)\end{array}$ & $\begin{array}{l}-9.306 \\
(0.398)\end{array}$ & $\begin{array}{l}-10.524 \\
(0.360)\end{array}$ & $\begin{array}{l}-11.991 \\
(0.356)\end{array}$ & $\begin{array}{l}-11.474 \\
(0.406)\end{array}$ & $\begin{array}{l}-11.707 \\
(0.401)\end{array}$ & $\begin{array}{l}-12.128 \\
(0.388)\end{array}$ & $\begin{array}{l}-12.549 \\
(0.426)\end{array}$ \\
\hline $\begin{array}{l}\text { FT fixed- } \\
\text { term }\end{array}$ & $\begin{array}{l}0.956 \\
(0.297)\end{array}$ & $\begin{array}{l}1.065 \\
(0.255)\end{array}$ & $\begin{array}{l}1.175 \\
(0.262)\end{array}$ & $\begin{array}{l}1.284 \\
(0.315)\end{array}$ & $\begin{array}{l}1.281 \\
(0.326)\end{array}$ & $\begin{array}{l}1.195 \\
(0.348)\end{array}$ & $\begin{array}{l}1.110 \\
(0.381)\end{array}$ & $\begin{array}{l}1.024 \\
(0.422)\end{array}$ & $\begin{array}{l}0.938 \\
(0.470)\end{array}$ \\
\hline $\mathrm{NE}$ & $\begin{array}{l}-2.941 \\
(0.403) \\
\end{array}$ & $\begin{array}{l}-5.841 \\
(0.421) \\
\end{array}$ & $\begin{array}{l}-8.892 \\
(0.430)\end{array}$ & $\begin{array}{l}-13.850 \\
(0.417) \\
\end{array}$ & $\begin{array}{l}-21.090 \\
(0.455)\end{array}$ & $\begin{array}{l}-25.821 \\
(0.498)\end{array}$ & $\begin{array}{l}-30.080 \\
(0.528)\end{array}$ & $\begin{array}{l}-30.136 \\
(0.571)\end{array}$ & $\begin{array}{l}-30.192 \\
(0.652)\end{array}$ \\
\hline \multicolumn{10}{|c|}{ Panel C: Childless Women } \\
\hline \multicolumn{10}{|c|}{ Quarters / Years in that state } \\
\hline & Q1 & Q2 & Q3 & Q4 & $\mathrm{Y} 2$ & Y3 & Y4 & Y5 & Y6 \\
\hline $\begin{array}{l}\text { PT fixed- } \\
\text { term }\end{array}$ & $\begin{array}{l}-4.515 \\
(0.731)\end{array}$ & $\begin{array}{l}-5.315 \\
(0.755)\end{array}$ & $\begin{array}{l}-7.463 \\
(0.804)\end{array}$ & $\begin{array}{l}-9.939 \\
(0.823)\end{array}$ & $\begin{array}{c}-8.607 \\
(0.897)\end{array}$ & $\begin{array}{c}-9.085 \\
(0.968)\end{array}$ & $\begin{array}{l}-13.285 \\
(1.007)\end{array}$ & $\begin{array}{l}-15.600 \\
(1.010)\end{array}$ & $\begin{array}{l}-17.914 \\
(1.079)\end{array}$ \\
\hline $\begin{array}{c}\text { PT } \\
\text { Permanent }\end{array}$ & $\begin{array}{l}-9.838 \\
(0.656)\end{array}$ & $\begin{array}{l}-11.322 \\
(0.616)\end{array}$ & $\begin{array}{l}-14.154 \\
(0.618)\end{array}$ & $\begin{array}{l}-17.313 \\
(0.595)\end{array}$ & $\begin{array}{l}-15.951 \\
(0.583)\end{array}$ & $\begin{array}{l}-16.250 \\
(0.664)\end{array}$ & $\begin{array}{l}-20.269 \\
(0.686)\end{array}$ & $\begin{array}{l}-22.405 \\
(0.645)\end{array}$ & $\begin{array}{l}-24.540 \\
(0.707)\end{array}$ \\
\hline $\begin{array}{l}\text { FT fixed- } \\
\text { term }\end{array}$ & $\begin{array}{l}1.541 \\
(0.320)\end{array}$ & $\begin{array}{l}1.520 \\
(0.279)\end{array}$ & $\begin{array}{l}1.499 \\
(0.290)\end{array}$ & $\begin{array}{l}1.478 \\
(0.348)\end{array}$ & $\begin{array}{l}1.448 \\
(0.370)\end{array}$ & $\begin{array}{l}1.268 \\
(0.388)\end{array}$ & $\begin{array}{l}1.088 \\
(0.419)\end{array}$ & $\begin{array}{l}0.909 \\
(0.461)\end{array}$ & $\begin{array}{l}0.729 \\
(0.511)\end{array}$ \\
\hline $\mathrm{NE}$ & $\begin{array}{l}-3.518 \\
(0.522)\end{array}$ & $\begin{array}{l}-8.324 \\
(0.548)\end{array}$ & $\begin{array}{l}-11.457 \\
(0.567)\end{array}$ & $\begin{array}{l}-17.153 \\
(0.560)\end{array}$ & $\begin{array}{l}-26.882 \\
(0.605)\end{array}$ & $\begin{array}{l}-32.166 \\
(0.671)\end{array}$ & $\begin{array}{l}-40.082 \\
(0.731)\end{array}$ & $\begin{array}{l}-42.225 \\
(0.796)\end{array}$ & $\begin{array}{l}-44.368 \\
(0.923)\end{array}$ \\
\hline
\end{tabular}

Note: Standard errors are multiplied by 100 and are in parentheses. 
Table 5

Variance and Covariance Parameters (Means and Standard Deviations)

\begin{tabular}{|c|c|c|c|c|c|c|}
\hline & \multicolumn{2}{|c|}{$\begin{array}{l}\text { Panel A: } \\
\text { Whole Sample }\end{array}$} & \multicolumn{2}{|c|}{$\begin{array}{l}\text { Panel B: } \\
\text { Mothers (to be) }\end{array}$} & \multicolumn{2}{|c|}{$\begin{array}{l}\text { Panel C: } \\
\text { Childless }\end{array}$} \\
\hline & Mean & SD & Mean & SD & Mean & SD \\
\hline & \multicolumn{6}{|c|}{ Variance and Covariance Parameters } \\
\hline $\operatorname{Var}\left(\alpha^{\mathrm{W}}\right)$ & 0.1053 & 0.0012 & 0.1053 & 0.0016 & 0.1095 & 0.0020 \\
\hline $\operatorname{Var}\left(\varepsilon^{\mathrm{W}}\right)$ & 0.0211 & 0.0001 & 0.0219 & 0.0001 & 0.0202 & 0.0002 \\
\hline $\operatorname{Var}\left(\alpha^{\mathrm{C}}\right)$ & 0.2933 & 0.0204 & 0.3454 & 0.0267 & 0.3528 & 0.0267 \\
\hline $\operatorname{Var}\left(\alpha^{\mathrm{E}}\right)$ & 0.4969 & 0.0162 & 0.4609 & 0.0187 & 0.5791 & 0.0323 \\
\hline $\operatorname{Cov}\left(\alpha^{\mathrm{W}}, \alpha^{\mathrm{E}}\right)$ & 0.0470 & 0.0028 & 0.0485 & 0.0035 & 0.0392 & 0.0050 \\
\hline $\operatorname{Cov}\left(\alpha^{\mathrm{W}}, \alpha^{\mathrm{C}}\right)$ & -0.0254 & 0.0033 & -0.0285 & 0.0045 & -0.0218 & 0.0051 \\
\hline $\operatorname{Cov}\left(\alpha^{\mathrm{C}}, \alpha^{\mathrm{E}}\right)$ & -0.0665 & 0.0115 & -0.0560 & 0.0140 & -0.0907 & 0.0189 \\
\hline $\operatorname{Var}\left(\alpha^{\mathrm{W}}\right) /\left(\operatorname{Var}\left(\alpha^{\mathrm{W}}\right)+\operatorname{Var}\left(\varepsilon^{\mathrm{W}}\right)\right)$ & 0.8330 & 0.0017 & 0.8280 & 0.0023 & 0.8441 & 0.0026 \\
\hline $\operatorname{Var}\left(\alpha^{\mathrm{C}}\right) /\left(\operatorname{Var}\left(\alpha^{\mathrm{C}}\right)+1\right)$ & 0.2266 & 0.0122 & 0.2564 & 0.0147 & 0.2605 & 0.0146 \\
\hline $\operatorname{Var}\left(\alpha^{\mathrm{E}}\right) /\left(\operatorname{Var}\left(\alpha^{\mathrm{E}}\right)+1\right)$ & 0.3319 & 0.0072 & 0.3154 & 0.0088 & 0.3665 & 0.0130 \\
\hline $\operatorname{Corr}\left(\alpha^{\mathrm{W}}, \alpha^{\mathrm{E}}\right)$ & 0.2053 & 0.0118 & 0.2204 & 0.0148 & 0.1559 & 0.0191 \\
\hline $\operatorname{Corr}\left(\alpha^{\mathrm{W}}, \alpha^{\mathrm{C}}\right)$ & -0.1448 & 0.0179 & -0.1498 & 0.0224 & -0.1111 & 0.0252 \\
\hline $\operatorname{Corr}\left(\alpha^{\mathrm{C}}, \alpha^{\mathrm{E}}\right)$ & -0.1741 & 0.0281 & -0.1402 & 0.0339 & -0.2005 & 0.0396 \\
\hline
\end{tabular}

Table 6

Sensitivity Analysis: Estimated Cumulative Returns Estimated from Alternative Models All Women

\begin{tabular}{|c|c|c|c|c|c|c|c|c|c|}
\hline \multicolumn{10}{|c|}{ Panel A: Standard RE Model } \\
\hline & \multicolumn{9}{|c|}{ Quarters/Years in that state } \\
\hline & Q1 & Q2 & Q3 & Q4 & Y2 & Y3 & Y4 & Y5 & Y6 \\
\hline PT fixed-term & $\begin{array}{l}-8.139 \\
(0.430)\end{array}$ & $\begin{array}{c}-10.034 \\
(0.432)\end{array}$ & $\begin{array}{l}-11.644 \\
(0.452)\end{array}$ & $\begin{array}{l}-13.091 \\
(0.461)\end{array}$ & $\begin{array}{l}-13.948 \\
(0.496)\end{array}$ & $\begin{array}{l}-13.750 \\
(0.533)\end{array}$ & $\begin{array}{l}-15.231 \\
(0.545)\end{array}$ & $\begin{array}{l}-16.083 \\
(0.561)\end{array}$ & $\begin{array}{l}-16.934 \\
(0.604)\end{array}$ \\
\hline PT Permanent & $\begin{array}{l}-6.274 \\
(0.334)\end{array}$ & $\begin{array}{l}-8.510 \\
(0.325)\end{array}$ & $\begin{array}{l}-10.461 \\
(0.331)\end{array}$ & $\begin{array}{l}-12.247 \\
(0.304)\end{array}$ & $\begin{array}{l}-13.049 \\
(0.302)\end{array}$ & $\begin{array}{l}-12.711 \\
(0.342)\end{array}$ & $\begin{array}{l}-14.052 \\
(0.343)\end{array}$ & $\begin{array}{l}-14.762 \\
(0.328)\end{array}$ & $\begin{array}{l}-15.473 \\
(0.360)\end{array}$ \\
\hline FT fixed-term & $\begin{array}{l}1.088 \\
(0.216) \\
\end{array}$ & $\begin{array}{l}1.134 \\
(0.187) \\
\end{array}$ & $\begin{array}{l}1.180 \\
(0.193)\end{array}$ & $\begin{array}{l}1.227 \\
(0.232) \\
\end{array}$ & $\begin{array}{l}1.171 \\
(0.243) \\
\end{array}$ & $\begin{array}{l}1.030 \\
(0.257) \\
\end{array}$ & $\begin{array}{l}0.890 \\
(0.280) \\
\end{array}$ & $\begin{array}{l}0.749 \\
(0.340) \\
\end{array}$ & $\begin{array}{l}0.609 \\
(0.340)\end{array}$ \\
\hline $\mathrm{NE}$ & $\begin{array}{l}-3.157 \\
(0.317)\end{array}$ & $\begin{array}{l}-6.765 \\
(0.324)\end{array}$ & $\begin{array}{l}-9.843 \\
(0.334)\end{array}$ & $\begin{array}{l}-15.058 \\
(0.331)\end{array}$ & $\begin{array}{l}-23.195 \\
(0.359)\end{array}$ & $\begin{array}{l}-28.147 \\
(0.394)\end{array}$ & $\begin{array}{l}-33.703 \\
(0.423)\end{array}$ & $\begin{array}{l}-34.457 \\
(0.458)\end{array}$ & $\begin{array}{l}-35.212 \\
(0.524)\end{array}$ \\
\hline \multicolumn{10}{|c|}{ Panel B: FE Model } \\
\hline & \multicolumn{9}{|c|}{ Quarters/Years in that state } \\
\hline & Q1 & Q2 & Q3 & Q4 & Y2 & Y3 & Y4 & Y5 & Y6 \\
\hline PT fixed-term & $\begin{array}{l}-7.706 \\
(0.431)\end{array}$ & $\begin{array}{l}-9.571 \\
(0.433)\end{array}$ & $\begin{array}{l}-11.162 \\
(0.454)\end{array}$ & $\begin{array}{l}-12.544 \\
(0.463)\end{array}$ & $\begin{array}{l}-13.311 \\
(0.499)\end{array}$ & $\begin{array}{l}-13.037 \\
(0.537)\end{array}$ & $\begin{array}{l}-14.444 \\
(0.548)\end{array}$ & $\begin{array}{l}-15.245 \\
(0.565)\end{array}$ & $\begin{array}{l}-16.045 \\
(0.609)\end{array}$ \\
\hline PT Permanent & $\begin{array}{l}-6.063 \\
(0.340)\end{array}$ & $\begin{array}{l}-8.293 \\
(0.325) \\
\end{array}$ & $\begin{array}{l}-10.248 \\
(0.331) \\
\end{array}$ & $\begin{array}{l}-11.995 \\
(0.305)\end{array}$ & $\begin{array}{l}-12.761 \\
(0.303) \\
\end{array}$ & $\begin{array}{l}-12.386 \\
(0.343) \\
\end{array}$ & $\begin{array}{l}-13.688 \\
(0.344)\end{array}$ & $\begin{array}{l}-14.383 \\
(0.330) \\
\end{array}$ & $\begin{array}{l}-15.078 \\
(0.361)\end{array}$ \\
\hline FT fixed-term & $\begin{array}{l}1.103 \\
(0.217) \\
\end{array}$ & $\begin{array}{l}1.165 \\
(0.188) \\
\end{array}$ & $\begin{array}{l}1.226 \\
(0.195) \\
\end{array}$ & $\begin{array}{l}1.288 \\
(0.233) \\
\end{array}$ & $\begin{array}{l}1.293 \\
(0.245) \\
\end{array}$ & $\begin{array}{l}1.187 \\
(0.259) \\
\end{array}$ & $\begin{array}{l}1.081 \\
(0.283) \\
\end{array}$ & $\begin{array}{l}0.976 \\
(0.313) \\
\end{array}$ & $\begin{array}{l}0.870 \\
(0.347) \\
\end{array}$ \\
\hline $\mathrm{NE}$ & $\begin{array}{l}-3.137 \\
(0.313) \\
\end{array}$ & $\begin{array}{c}-6.738 \\
(0.323) \\
\end{array}$ & $\begin{array}{c}-9.797 \\
(0.340) \\
\end{array}$ & $\begin{array}{l}-14.982 \\
(0.331) \\
\end{array}$ & $\begin{array}{l}-23.034 \\
(0.360) \\
\end{array}$ & $\begin{array}{l}-27.905 \\
(0.340) \\
\end{array}$ & $\begin{array}{l}-33.398 \\
(0.425) \\
\end{array}$ & $\begin{array}{l}-34.036 \\
(0.462) \\
\end{array}$ & $\begin{array}{l}-34.674 \\
(0.531)\end{array}$ \\
\hline \multicolumn{10}{|c|}{ Panel C: Pooled OLS } \\
\hline & \multicolumn{9}{|c|}{ Quarters/Years in that state } \\
\hline & Q1 & Q2 & Q3 & Q4 & Y2 & Y3 & Y4 & Y5 & Y6 \\
\hline PT fixed-term & $\begin{array}{l}-22.465 \\
(0.911)\end{array}$ & $\begin{array}{l}-25.075 \\
(0.876)\end{array}$ & $\begin{array}{l}-27.358 \\
(0.876)\end{array}$ & $\begin{array}{l}-30.649 \\
(0.840)\end{array}$ & $\begin{array}{l}-35.623 \\
(0.853)\end{array}$ & $\begin{array}{l}-37.732 \\
(0.918) \\
\end{array}$ & $\begin{array}{l}-43.786 \\
(0.880)\end{array}$ & $\begin{array}{c}-45.108 \\
(0.884)\end{array}$ & $\begin{array}{l}-46.430 \\
(0.883)\end{array}$ \\
\hline PT Permanent & $\begin{array}{l}-17.056 \\
(0.760)\end{array}$ & $\begin{array}{l}-19.877 \\
(0.715) \\
\end{array}$ & $\begin{array}{l}-22.371 \\
(0.720) \\
\end{array}$ & $\begin{array}{l}-25.874 \\
(0.640)\end{array}$ & $\begin{array}{l}-28.989 \\
(0.618)\end{array}$ & $\begin{array}{l}-29.289 \\
(0.696) \\
\end{array}$ & $\begin{array}{l}-33.533 \\
(0.638)\end{array}$ & $\begin{array}{l}-33.046 \\
(0.555) \\
\end{array}$ & $\begin{array}{l}-32.558 \\
(0.589)\end{array}$ \\
\hline FT fixed-term & $\begin{array}{l}-0.407 \\
(0.445)\end{array}$ & $\begin{array}{l}-0.980 \\
(0.342)\end{array}$ & $\begin{array}{l}-1.552 \\
(0.333)\end{array}$ & $\begin{array}{l}-2.125 \\
(0.423)\end{array}$ & $\begin{array}{l}-3.984 \\
(0.379)\end{array}$ & $\begin{array}{l}-5.794 \\
(0.369)\end{array}$ & $\begin{array}{l}-7.603 \\
(0.381)\end{array}$ & $\begin{array}{l}-9.413 \\
(0.414)\end{array}$ & $\begin{array}{l}-11.222 \\
(0.463)\end{array}$ \\
\hline $\mathrm{NE}$ & $\begin{array}{l}-4.622 \\
(0.743)\end{array}$ & $\begin{array}{l}-9.042 \\
(0.764)\end{array}$ & $\begin{array}{l}-13.173 \\
(0.778)\end{array}$ & $\begin{array}{l}-19.948 \\
(0.751)\end{array}$ & $\begin{array}{l}-31.710 \\
(0.779)\end{array}$ & $\begin{array}{l}-39.662 \\
(0.817)\end{array}$ & $\begin{array}{l}-47.566 \\
(0.818)\end{array}$ & $\begin{array}{l}-50.544 \\
(0.795)\end{array}$ & $\begin{array}{l}-53.523 \\
(0.825)\end{array}$ \\
\hline
\end{tabular}

Note: Standard errors are multiplied by 100 and are in parentheses. 
APPENDIX

(Not necessarily for publication) 
Table A.1

Main Specification (Means and Standard Deviations of Parameters)

\begin{tabular}{|c|c|c|c|c|c|c|}
\hline & \multicolumn{2}{|c|}{ Whole Sample } & \multicolumn{2}{|c|}{ Mothers (to be) } & \multicolumn{2}{|c|}{ Childless } \\
\hline & Mean & SD & Mean & SD & Mean & SD \\
\hline & \multicolumn{6}{|c|}{ Wage Equation } \\
\hline PT & -0.0018 & 0.0036 & 0.0075 & 0.0042 & -0.0305 & 0.0068 \\
\hline PTlag1 & -0.0601 & 0.0045 & -0.0592 & 0.0053 & -0.0678 & 0.0086 \\
\hline PTlag2 & -0.0223 & 0.0038 & -0.0258 & 0.0046 & -0.0148 & 0.0067 \\
\hline PTlag3 & -0.0194 & 0.0038 & -0.0156 & 0.0047 & -0.0283 & 0.0067 \\
\hline PTlag4 & -0.0179 & 0.0036 & -0.0122 & 0.0044 & -0.0316 & 0.0066 \\
\hline PTlag5 + PTlag6 + PTlag7 + PTlag8 & -0.0020 & 0.0010 & -0.0037 & 0.0011 & 0.0034 & 0.0018 \\
\hline PTlag9 + PTlag10 + PTlag11 + PTlag12 & 0.0009 & 0.0010 & 0.0013 & 0.0012 & -0.0007 & 0.0019 \\
\hline PTlag13 + PTlag14 + PTlag15 + PTlag16 & -0.0033 & 0.0010 & -0.0006 & 0.0011 & -0.0100 & 0.0019 \\
\hline PTlag17 + PTlag18 + ... + PTlag40 & -0.0018 & 0.0003 & -0.0011 & 0.0004 & -0.0053 & 0.0007 \\
\hline NElag1 & -0.0310 & 0.0032 & -0.0294 & 0.0040 & -0.0352 & 0.0052 \\
\hline NElag2 & -0.0357 & 0.0028 & -0.0290 & 0.0035 & -0.0481 & 0.0045 \\
\hline NElag3 & -0.0304 & 0.0027 & -0.0305 & 0.0035 & -0.0313 & 0.0044 \\
\hline NElag4 & -0.0519 & 0.0025 & -0.0496 & 0.0032 & -0.0570 & 0.0042 \\
\hline NElag5 + NElag6 +NElag7 +NElag8 & -0.0201 & 0.0007 & -0.0181 & 0.0009 & -0.0243 & 0.0012 \\
\hline NElag9 + NElag10 + NElag11 +NElag12 & -0.0121 & 0.0007 & -0.0118 & 0.0009 & -0.0132 & 0.0012 \\
\hline NElag13 +NElag14 + NElag15 +NElag16 & -0.0137 & 0.0007 & -0.0106 & 0.0009 & -0.0198 & 0.0012 \\
\hline NElag17 + NElag18 + ... + NElag40 & -0.0016 & 0.0003 & -0.0001 & 0.0004 & -0.0054 & 0.0006 \\
\hline FIX and FT & 0.0293 & 0.0026 & 0.0357 & 0.0035 & 0.0220 & 0.0039 \\
\hline FIX and PT & -0.0496 & 0.0050 & -0.0650 & 0.0062 & -0.0049 & 0.0089 \\
\hline FIXlag1 and FTlag1 & -0.0174 & 0.0029 & -0.0261 & 0.0039 & -0.0066 & 0.0043 \\
\hline FIXlag1 and PTlag1 & 0.0321 & 0.0057 & 0.0232 & 0.0071 & 0.0581 & 0.0103 \\
\hline FIXlag2 +FIXlag3 +FIXlag4 and PT in none & 0.0005 & 0.0008 & 0.0011 & 0.0012 & -0.0002 & 0.0012 \\
\hline FIXlag2 +FIXlag3 +FIXlag4 and PT in min. one & 0.0036 & 0.0016 & 0.0034 & 0.0020 & 0.0068 & 0.0029 \\
\hline FIXlag5 +FIXlag6 +FIXlag7 +FIXlag8 & -0.0001 & 0.0005 & -0.0000 & 0.0007 & -0.0001 & 0.0008 \\
\hline FIXlag9 +FIXlag10 + ... +FIXlag40 & -0.0003 & 0.0001 & -0.0002 & 0.0002 & -0.0004 & 0.0002 \\
\hline Not in sample lag2 & -0.0651 & 0.0025 & -0.0626 & 0.0032 & -0.0665 & 0.0037 \\
\hline Not in sample lag3 & -0.0556 & 0.0022 & -0.0533 & 0.0029 & -0.0567 & 0.0033 \\
\hline Not in sample lag4 & -0.0477 & 0.0020 & -0.0449 & 0.0026 & -0.0498 & 0.0030 \\
\hline Not in sample in lag5 $+\ldots$ lag6 $+\ldots$ lag7 $+\ldots$ lag8 & -0.0348 & 0.0013 & -0.0343 & 0.0016 & -0.0345 & 0.0019 \\
\hline Not in sample in lag9 $+\ldots+\ldots$ lag12 & 0.0060 & 0.0009 & 0.0053 & 0.0011 & 0.0067 & 0.0013 \\
\hline Not in sample in lag13 + .. + ..lag16 & 0.0058 & 0.0007 & 0.0057 & 0.0010 & 0.0058 & 0.0011 \\
\hline Not in sample in lag17 $+\ldots+\ldots$ lag 40 & 0.0114 & 0.0011 & 0.0135 & 0.0015 & 0.0083 & 0.0016 \\
\hline $\mathrm{PT}$ in $\mathrm{t}=0$ & -0.2030 & 0.0212 & -0.1994 & 0.0254 & -0.2594 & 0.0510 \\
\hline $\mathrm{NE}$ in $\mathrm{t}=0$ & -0.0631 & 0.0169 & -0.0689 & 0.0200 & -0.0775 & 0.0326 \\
\hline Experience in FT in $\mathrm{t}=0$ & 0.0133 & 0.0009 & 0.0120 & 0.0012 & 0.0157 & 0.0016 \\
\hline Experience in $\mathrm{PT}$ in $\mathrm{t}=0$ & -0.0140 & 0.0036 & -0.0128 & 0.0045 & -0.0157 & 0.0059 \\
\hline FIX in $\mathrm{t}=0$ & -0.0221 & 0.0112 & -0.0088 & 0.0166 & -0.0402 & 0.0171 \\
\hline Experience in FIX in $\mathrm{t}=0$ & -0.0033 & 0.0132 & -0.0275 & 0.0178 & 0.0277 & 0.0190 \\
\hline Age from 23 to 29 & -0.0201 & 0.0019 & -0.0187 & 0.0025 & -0.0223 & 0.0029 \\
\hline Age from 30 to 34 & -0.0038 & 0.0010 & -0.0029 & 0.0013 & -0.0050 & 0.0015 \\
\hline Age from 40 to 45 & -0.0076 & 0.0011 & -0.0058 & 0.0014 & -0.0119 & 0.0017 \\
\hline Less than secondary education & -0.2198 & 0.0063 & -0.2228 & 0.0084 & -0.2149 & 0.0103 \\
\hline More than secondary education & 0.3540 & 0.0066 & 0.3539 & 0.0093 & 0.3590 & 0.0095 \\
\hline No child & 0.0188 & 0.0018 & 0.0232 & 0.0023 & & \\
\hline Youngest child younger than 2 years & -0.0033 & 0.0014 & -0.0014 & 0.0016 & & \\
\hline Youngest child 3 years & -0.0052 & 0.0015 & -0.0038 & 0.0017 & & \\
\hline Youngest child 4 to $6 y e a r s$ & -0.0040 & 0.0012 & -0.0033 & 0.0012 & & \\
\hline 1997 & 0.0562 & 0.0105 & 0.0587 & 0.0131 & 0.0406 & 0.0155 \\
\hline 1998 & 0.0481 & 0.0094 & 0.0514 & 0.0116 & 0.0340 & 0.0137 \\
\hline 1999 & 0.0493 & 0.0082 & 0.0549 & 0.0102 & 0.0327 & 0.0121 \\
\hline 2000 & 0.0309 & 0.0071 & 0.0348 & 0.0088 & 0.0183 & 0.0104 \\
\hline 2001 & 0.0264 & 0.0059 & 0.0294 & 0.0074 & 0.0162 & 0.0087 \\
\hline 2002 & 0.0209 & 0.0048 & 0.0241 & 0.0059 & 0.0116 & 0.0070 \\
\hline 2003 & 0.0240 & 0.0036 & 0.0263 & 0.0045 & 0.0171 & 0.0053 \\
\hline 2004 & 0.0144 & 0.0025 & 0.0175 & 0.0031 & 0.0076 & 0.0037 \\
\hline 2005 & 0.0124 & 0.0015 & 0.0143 & 0.0019 & 0.0087 & 0.0022 \\
\hline April to June & -0.0061 & 0.0007 & -0.0059 & 0.0009 & -0.0061 & 0.0011 \\
\hline July to September & -0.0102 & 0.0009 & -0.0101 & 0.0011 & -0.0099 & 0.0013 \\
\hline
\end{tabular}




\begin{tabular}{|c|c|c|c|c|c|c|}
\hline October to December & -0.0143 & 0.0011 & -0.0138 & 0.0014 & -0.0139 & 0.0016 \\
\hline UR in province (deviation) & -0.0003 & 0.0001 & -0.0005 & 0.0002 & 0.0001 & 0.0002 \\
\hline GDP growth in province (deviation) & 0.0487 & 0.0162 & 0.0648 & 0.0211 & 0.0167 & 0.0254 \\
\hline \multirow[t]{2}{*}{ Constant } & 2.1581 & 0.0082 & 2.1723 & 0.0108 & 2.1566 & 0.0121 \\
\hline & \multicolumn{6}{|c|}{ Contract Equation } \\
\hline FIXlag1 & 3.6431 & 0.0408 & 3.6708 & 0.0617 & 3.6320 & 0.0736 \\
\hline FIXlag2 & -0.0266 & 0.0368 & -0.0250 & 0.0503 & -0.0469 & 0.0577 \\
\hline FIXlag3 & 0.1461 & 0.0381 & 0.1517 & 0.0524 & 0.1408 & 0.0598 \\
\hline FIXlag4 & 0.0177 & 0.0367 & -0.0066 & 0.0505 & 0.0351 & 0.0571 \\
\hline FIXlag5 + FIXlag6 + FIXlag7 + FIXlag8 & 0.0863 & 0.0117 & 0.0907 & 0.0160 & 0.0718 & 0.0182 \\
\hline FIXlag9 + FIXlag10 + FIXlag11 + FIXlag12 & 0.0397 & 0.0129 & 0.0442 & 0.0174 & 0.0266 & 0.0201 \\
\hline FIXlag13 + FIXlag14 + FIXlag15 + FIXlag16 & -0.0559 & 0.0120 & -0.0880 & 0.0165 & -0.0305 & 0.0194 \\
\hline PT & 0.4620 & 0.0384 & 0.3255 & 0.0484 & 0.7476 & 0.0700 \\
\hline PTlag1 & -0.1905 & 0.0549 & -0.1513 & 0.0685 & -0.2638 & 0.0889 \\
\hline PTlag2 + PTlag3 + PTlag4 & -0.0460 & 0.0229 & -0.0143 & 0.0290 & -0.1086 & 0.0392 \\
\hline PTlag5 + PTlag6 + PTlag7 + PTlag8 & 0.0427 & 0.0192 & 0.0517 & 0.0234 & 0.0258 & 0.0354 \\
\hline PTlag9 + PTlag10 + PTlag11 + PTlag12 & -0.0569 & 0.0187 & -0.0702 & 0.0230 & -0.0104 & 0.0355 \\
\hline NElag1 & 2.6261 & 0.0475 & 2.5961 & 0.0698 & 2.7362 & 0.0863 \\
\hline NElag2 +NElag3 +NElag4 & 0.1619 & 0.0166 & 0.1762 & 0.0222 & 0.1649 & 0.0276 \\
\hline NElag5 + NElag6 +NElag7 +NElag8 & 0.0581 & 0.0129 & 0.0792 & 0.0171 & 0.0285 & 0.0210 \\
\hline NElag9 + NElag10 + NElag11 +NElag12 & 0.0360 & 0.0129 & 0.0382 & 0.0162 & 0.0346 & 0.0211 \\
\hline FIX in $\mathrm{t}=0$ & 0.3842 & 0.0686 & 0.4051 & 0.1103 & 0.5087 & 0.1231 \\
\hline Experience in FIX in $\mathrm{t}=0$ & 0.5107 & 0.0807 & 0.5970 & 0.1150 & 0.4539 & 0.1177 \\
\hline Not in sample lag2 & 0.3479 & 0.0441 & 0.4515 & 0.0677 & 0.2570 & 0.0713 \\
\hline Not in sample lag3 & 0.3114 & 0.0423 & 0.3287 & 0.0643 & 0.3119 & 0.0692 \\
\hline Not in sample lag4 & 0.2592 & 0.0417 & 0.3788 & 0.0629 & 0.1255 & 0.0663 \\
\hline Not in sample in lag5 $+\ldots$ lag6 $+\ldots$ lag7 $+\ldots$ lag8 & 0.1442 & 0.0183 & 0.1622 & 0.0292 & 0.1216 & 0.0295 \\
\hline Not in sample in lag9 $+\ldots+\ldots$. .lag12 & -0.1149 & 0.0269 & -0.1235 & 0.0403 & -0.1065 & 0.0417 \\
\hline Not in sample in lag13 $+\ldots+\ldots$ lag16 & -0.0127 & 0.0238 & -0.0279 & 0.0332 & 0.0080 & 0.0349 \\
\hline Not in sample in lag17 $+\ldots+\ldots$ lag 40 & 0.0138 & 0.0342 & 0.0567 & 0.0496 & -0.0217 & 0.0526 \\
\hline Age from 23 to 29 & 0.1827 & 0.0512 & 0.2138 & 0.0761 & 0.1646 & 0.0774 \\
\hline Age from 30 to 34 & 0.0253 & 0.0251 & 0.0074 & 0.0393 & 0.0432 & 0.0387 \\
\hline Age from 40 to 45 & -0.0545 & 0.0299 & -0.0255 & 0.0369 & -0.0956 & 0.0520 \\
\hline Less than secondary education & 0.1099 & 0.0477 & 0.1335 & 0.0708 & 0.0805 & 0.0910 \\
\hline More than secondary education & 0.0619 & 0.0544 & 0.0223 & 0.0738 & 0.1092 & 0.0754 \\
\hline No child & -0.0244 & 0.0408 & 0.0111 & 0.0620 & & \\
\hline Youngest child younger than 2 years & -0.2182 & 0.0391 & -0.1698 & 0.0480 & & \\
\hline Youngest child 3 years & -0.1064 & 0.0524 & -0.0791 & 0.0581 & & \\
\hline Youngest child 4 to 6years & -0.0740 & 0.0380 & -0.0548 & 0.0423 & & \\
\hline 1997 & -0.4784 & 0.0692 & -0.5254 & 0.1099 & -0.4737 & 0.1330 \\
\hline 1998 & -0.4529 & 0.0651 & -0.4822 & 0.1053 & -0.4283 & 0.1274 \\
\hline 1999 & -0.3778 & 0.0651 & -0.3807 & 0.0972 & -0.3914 & 0.1180 \\
\hline 2000 & -0.1452 & 0.0523 & -0.1334 & 0.0767 & -0.1565 & 0.0884 \\
\hline 2001 & -0.0725 & 0.0453 & -0.0754 & 0.0673 & -0.0705 & 0.0761 \\
\hline 2002 & -0.0080 & 0.0389 & -0.0545 & 0.0586 & 0.0400 & 0.0601 \\
\hline 2003 & 0.0103 & 0.0342 & -0.0139 & 0.0480 & 0.0336 & 0.0537 \\
\hline 2004 & 0.0696 & 0.0305 & 0.0548 & 0.0425 & 0.0861 & 0.0466 \\
\hline 2005 & 0.0869 & 0.0268 & 0.0813 & 0.0379 & 0.0966 & 0.0419 \\
\hline April to June & 0.1194 & 0.0230 & 0.1619 & 0.0314 & 0.0704 & 0.0348 \\
\hline July to September & 0.0752 & 0.0225 & 0.1426 & 0.0315 & -0.0125 & 0.0358 \\
\hline October to December & 0.0773 & 0.0224 & 0.1376 & 0.0311 & 0.0028 & 0.0349 \\
\hline UR in province (deviation) & -0.0002 & 0.0038 & 0.0004 & 0.0048 & -0.0001 & 0.0054 \\
\hline GDP growth in province (deviation) & -0.2397 & 0.5351 & 0.0733 & 0.7042 & -0.6148 & 0.8391 \\
\hline \multirow[t]{2}{*}{ Constant } & -3.1721 & 0.0701 & -3.3147 & 0.1064 & -3.2029 & 0.1153 \\
\hline & \multicolumn{6}{|c|}{ Employment Equation } \\
\hline PTlag1 & -2.192 & 0.0305 & -2.203 & 0.0376 & -2.204 & 0.0679 \\
\hline PTlag2 + PTlag3 + PTlag4 & -0.0116 & 0.0108 & -0.0109 & 0.0126 & -0.0147 & 0.0219 \\
\hline PTlag5 + PTlag6 + PTlag7 + PTlag8 & -0.0191 & 0.0075 & -0.0209 & 0.0087 & -0.0126 & 0.0149 \\
\hline PTlag9 + PTlag10 + PTlag11 + PTlag12 & 0.0013 & 0.0067 & -0.0012 & 0.0077 & 0.0071 & 0.0133 \\
\hline NElag1 & -3.123 & 0.0239 & -3.2060 & 0.0307 & -2.9731 & 0.0496 \\
\hline NElag2 +NElag3 +NElag4 & -0.0221 & 0.0085 & -0.0145 & 0.0104 & -0.0346 & 0.0152 \\
\hline NElag5 + NElag6 +NElag7 +NElag8 & 0.0165 & 0.0064 & 0.0096 & 0.0077 & 0.0288 & 0.0116 \\
\hline NElag9 + NElag10 + NElag11 +NElag12 & 0.0814 & 0.0061 & 0.0757 & 0.0073 & 0.0964 & 0.0113 \\
\hline FIXlag1 and FTlag1 & -0.9409 & 0.0280 & -0.9499 & 0.0370 & -0.9255 & 0.0509 \\
\hline FIXlag1 and PTlag1 & -0.0381 & 0.0328 & -0.0511 & 0.0392 & 0.0120 & 0.0622 \\
\hline
\end{tabular}




\begin{tabular}{|c|c|c|c|c|c|c|}
\hline FIXlag2 +FIXlag3 +FIXlag4 and PT in none & 0.1295 & 0.0107 & 0.1444 & 0.0139 & 0.1070 & 0.0177 \\
\hline FIXlag2 +FIXlag3 +FIXlag4 and PT in min. one & 0.0414 & 0.0132 & 0.0377 & 0.0158 & 0.0549 & 0.0248 \\
\hline FIXlag5 +FIXlag6 +FIXlag7 +FIXlag8 & 0.0168 & 0.0064 & 0.0091 & 0.0079 & 0.0280 & 0.0112 \\
\hline PT in $\mathrm{t}=0$ & -0.8221 & 0.0645 & -0.8070 & 0.0748 & -0.8861 & 0.1620 \\
\hline $\mathrm{NE}$ in $\mathrm{t}=0$ & -1.023 & 0.0576 & -1.023 & 0.0707 & -1.019 & 0.1254 \\
\hline Not in sample lag2 & -0.0122 & 0.0302 & -0.0658 & 0.0378 & 0.0738 & 0.0527 \\
\hline Not in sample lag3 & 0.0056 & 0.0287 & 0.0101 & 0.0379 & -0.0038 & 0.0485 \\
\hline Not in sample lag4 & -0.0510 & 0.0282 & -0.0740 & 0.0354 & -0.0213 & 0.0475 \\
\hline Not in sample in lag5 $+\ldots$ lag6 $+\ldots$ lag7 $+\ldots$ lag8 & -0.0178 & 0.0119 & -0.0206 & 0.0154 & -0.0116 & 0.0200 \\
\hline Not in sample in lag $9+\ldots+\ldots$ lag12 & 0.0113 & 0.0163 & 0.0048 & 0.0202 & 0.0258 & 0.0269 \\
\hline Not in sample in lag13 $+\ldots+\ldots$ lag16 & 0.0061 & 0.0129 & 0.0174 & 0.0160 & -0.0179 & 0.0220 \\
\hline Not in sample in lag17 $+\ldots+\ldots$ lag40 & 0.0083 & 0.0188 & -0.0176 & 0.0235 & 0.0401 & 0.0322 \\
\hline Age from 23 to 29 & 0.0588 & 0.0360 & 0.0283 & 0.0450 & 0.0815 & 0.0604 \\
\hline Age from 30 to 34 & -0.0330 & 0.0148 & -0.0323 & 0.0180 & -0.0416 & 0.0267 \\
\hline Age from 40 to 45 & 0.1203 & 0.0166 & 0.1444 & 0.0205 & 0.0612 & 0.0312 \\
\hline Less than secondary education & -0.2379 & 0.0386 & -0.2321 & 0.0470 & -0.2463 & 0.0686 \\
\hline More than secondary education & 0.0741 & 0.0448 & 0.0953 & 0.0563 & 0.0440 & 0.0724 \\
\hline Experience in FT in $\mathrm{t}=0$ & 0.0242 & 0.0068 & 0.0225 & 0.0068 & 0.0287 & 0.0123 \\
\hline Experience in $\mathrm{PT}$ in $\mathrm{t}=0$ & -0.0114 & 0.0197 & -0.0150 & 0.0210 & -0.0021 & 0.0408 \\
\hline No child & 0.0504 & 0.0255 & 0.1218 & 0.0424 & & \\
\hline Youngest child younger than 2 years & -0.4530 & 0.0229 & -0.4415 & 0.0257 & & \\
\hline Youngest child 3 years & -0.1757 & 0.0261 & -0.1586 & 0.0275 & & \\
\hline Youngest child 4 to 6 years & -0.1077 & 0.0206 & -0.0981 & 0.0215 & & \\
\hline 1997 & 0.2084 & 0.0631 & 0.2090 & 0.0835 & 0.1965 & 0.1297 \\
\hline 1998 & -0.0113 & 0.0558 & -0.0046 & 0.0709 & -0.0613 & 0.1017 \\
\hline 1999 & -0.0860 & 0.0504 & -0.0851 & 0.0628 & -0.1226 & 0.0905 \\
\hline 2000 & -0.2032 & 0.0438 & -0.1860 & 0.0543 & -0.2664 & 0.0766 \\
\hline 2001 & -0.2961 & 0.0374 & -0.2835 & 0.0454 & -0.3320 & 0.0647 \\
\hline 2002 & -0.3483 & 0.0318 & -0.3083 & 0.0380 & -0.4365 & 0.0535 \\
\hline 2003 & -0.2812 & 0.0257 & -0.2663 & 0.0310 & -0.3174 & 0.0444 \\
\hline 2004 & -0.3048 & 0.0209 & -0.2858 & 0.0250 & -0.3474 & 0.0363 \\
\hline 2005 & -0.2468 & 0.0172 & -0.2378 & 0.0208 & -0.2665 & 0.0306 \\
\hline April to June & 0.0273 & 0.0123 & 0.0267 & 0.0142 & 0.0273 & 0.0219 \\
\hline July to September & 0.0495 & 0.0123 & 0.0552 & 0.0149 & 0.0410 & 0.0221 \\
\hline October to December & 0.0297 & 0.0127 & 0.0256 & 0.0153 & 0.0411 & 0.0221 \\
\hline UR in province (deviation) & 0.0042 & 0.0022 & 0.0039 & 0.0027 & 0.0043 & 0.0040 \\
\hline Constant & 3.7002 & 0.0529 & 3.7803 & 0.0639 & 3.6129 & 0.0874 \\
\hline
\end{tabular}

